\title{
Information Needs and Library Services Delivery for Students with Visual Impairment in Oyo State, Nigeria
}

Kolawole Akinjide ARAMIDE

kolaakinjide@gmail.com / ka.aramide@mail.ui.edu.ng

Centre for Educational Media Resource Studies

University of Ibadan, Nigeria

Wasiu Olayide LAWAL

Lawal022001@yahoo.co.uk

Nimbe Adedipe Library

Federal University of Agriculture, Abeokuta, Nigeria

Rachael Opeyemi ODUNLADE (PhD)

asheerman@gmail.com

University of Lagos Library

University of Lagos, Akoka, Lagos, Nigeria

This study investigated the information needs and library service delivery to students with visual impairment in Oyo State, Nigeria with a focus on assessing the influence of library 1 services;

information needs; media formats availability and accessibility on library use among students with visual impairment in Oyo State, Nigeria. The study established educational information, health information and information on coping with their visual impairment as major information needs of the visually impaired students while circulation service, reference service and screen reading service on computers are found to be the only library services provided for them. Print Books/Magazines, Braille Books and Braille-inPrint were found to be prominent among the few media-formats available for the students while the dearth of media-formats was found to be inadequate in meeting the information needs of students with visual impairment in Oyo State. Lack of ease of accessing the library resources, facilities as well as library staff whenever they need help, poor policy on borrowing privileges, lack of path sounders to guide their movement around the library among others were major accessibility issues confronting the students in enjoying quality library services. The study recommended the need to address the provision of basic facilities that are critical to effective library service delivery to the visually impaired students. 
Keywords: Information needs, Library service delivery, Media formats availability and accessibility, visually impaired students, Oyo State, Nigeria

\section{Introduction}

Library services delivery to students with visual impairment has continued to be a challenging task in Nigeria. This is because the type of resources required to deliver such services totally differs from the usual and conventional ones that can be used for other categories of challenged and non-challenged students. Studies (Mandesi, 2007; Ibenne, 2016; Rayini, 2017) and observations have also revealed that meeting the information needs of students with visual impairment in Nigeria with the right kind of library services including media-formats has continued to remain a seemingly unachievable task by school library media centres and school library media specialists. Whereas the importance of the school library media centres in providing information resources for self-development, self-actualisation, positive adaptation and life-long learning to all categories of individuals has long been established globally, it is a widely held view that school library media centres have being having issues providing library services for persons with visual impairment in Nigeria.

Visual impairment is a severe ophthalmological challenge that some people are born with or develop sometime in life due to a number of diverse causes. Of all the physiological and related morbidities, many people consider visual impairment as one that presents the most handicapping threats because it limits physical movement and the perception of information through sight. The handicap it presents in movement around unfamiliar environments, places persons with visual impairment at the state of needing assistance or assistive devices to reach desired places or objects, while the handicap in sight perception of information, places them at state of needing alternative means to those used by persons with sight in reading and other forms of communication other than oral. In other words, visual impairment is consider as a devastating physical and emotional condition with grave socio-economic implications such that all over the world people with visual impairments have to face numerous difficulties as they seek to assert their position in a modern, complex and competitive world dominated by able-bodied individuals. 
Consequently, this category of people are often excluded from social activities and are not treated in the same way as their able-bodied equals. The fact is that, in one way or another, their physical state means that they live a life that is perceived to be different from that of able-bodied people (Ochoggia 2003). Mandesi (2007) adds that people with disabilities face numerous challenges to access opportunities equal to those enjoyed by their peers in day-to-day life because environmental, physical, legal and institutional barriers are found throughout society while negative attitudes towards persons with disabilities often cause social exclusion and are the hardest to overcome. Mandesi further insists that, for people with disabilities to be treated equally, physical barriers to accessing resources need to be removed and attitudes towards them be changed. Hence, meeting their information needs should be given adequate attention.

As regards meeting their information needs, persons with visual impairment are usually faced with difficulties of using the regular information resources in form of print materials and also unable to perform the daily task or activity of reading standard print materials (Atkinson \& Dhiensa, 2007). Furthermore, there are various categorisations that have emerged for persons with visual impairment, basically aiming at differentiating those whose vision loss is total, final and absolute from those who have some impaired form of vision acuity. Whatever the case, persons with visual impairment do not exercise normal vision capabilities. Rayini (2017) categorised people with visual impairment into people who are partially-sighted or completely blind just as Nnadozie (2006) posits that persons with visual impairment can be categorised into the fully certified blind, individuals with low vision, astigmatic patients and the partially sighted.

According to the World Health Organization (2012), the number of people with visual impairment globally was 285 million with 39 million blind and 246 million having low vision; $65 \%$ of people with visual impairment and $82 \%$ of all blind are 50 years and older. Therefore, it is expedient that this category of people cannot be ignored as far as meeting their information needs and library service provision is concerned.

International Association of School Librarianship https://www.iasl-online.org/ 
Library service to persons with visual impairment in libraries refers to the specific professional assistance and other various forms of guidance given to them in the process of serving their information needs. Libraries, as the providers of information, should be at the forefront of removing the barriers hindering access to information, hence must be designed to be universally accessible, and universal access should be the norm; access for people with disabilities should not be an add-on to existing services. In summary, libraries should have equipment in place that facilitates both easy mobility and easier intellectual access for those who are challenged by visual impairments (Deines-Jones 2007). Ogba (2000) cited in Samuel (2016) believes that library services to students with visual impairment involves a special care and is a very important aspect of information services which have long been denied to these students, thus stripping them of opportunity that would have been of immense help in their everyday living. Thus, the importance of the library in the development of the individual is not in doubt, whatever type of service it offers. There is some doubt however, as to the quality of library service rendered to visually impaired students in most developing countries. White (2012) recognise the library as an essential tool in learning at any level, affirming that its services are very essential in achieving the educational aspirations of any individual, and that it is the repository for the society containing records not only of the intellectual but also of the cultural and social products.

The importance of school library media centres' services to students is grounded within the context of adequate provision of resources to support teaching, learning and curriculum which the school library media centres are expected to provide in order to facilitate the educational development of the students. In other words, the school library media centres are expected to be the anchor on which all teaching and learning activities in secondary schools revolve through the provision of useful media resources and conducive atmosphere for information use. The state of preparedness of school library media centres to play this expected role effectively, especially in developing countries, has become a source of worry to many. Added to that, is the extra level of personnel proficiency, media-formats and unique services needed to provide inclusive school library media centres service to students with visual impairment. 
The problem is better placed into perspective through an analysis of events globally. In the African situation, the paucity of library service to persons living with sight loss is captured by (Ibenne, 2016), who states that in most African countries the provision of library services has been geared more towards the sighted than the persons with visual impairment and that in the few cases that services are provided, they are mainly found in colleges and universities. This view slightly contrasts with Sanaman, \& Kumar (2014) who report in a close study of the facilities in place in most universities in Ghana that there was a neglect of the disabled, especially the students with visual impairment. In the case of India provision of service for the visually impaired persons by libraries is below standard because they have small collection of Braille and talking books (Census of India, 2011).

On the other hand, Babalola \& Haliso (2011) report that library services to persons with visual impairment in libraries of the developed countries like Britain, America, Canada, Australia, Finland and Netherlands are well established and that the services rendered have been enhanced tremendously in volumes and formats of presentation. They state further, that these countries have established national libraries for persons with visual impairment which ensured that their information needs are adequately catered for and gave the example of the UK VISION services in Europe which was established in 1992 to cater for the vision impaired readers in Britain by harnessing both local and national library materials and makes them available to borrowers with visual impairment alongside other citizens.

Unfortunately, in most African countries, the statistics of persons with visual impairment do not exist. In Zambia for example, Akakandelwa \& Munsanje (2012) lamented on the difficulty to provide precise figures for the prevalence of visual impairment. Oyegade (2003) cited in Ibenne (2016) puts the Nigerian situation in a grim cast by stating that the availability of library service provision opportunities in Nigeria, for the persons with visual impairment is very limited, with material providers working independently. There are no national statistical figures to give the 
total number of persons with visual impairment in Nigeria (Kyari et.al, 2009 and Abdull, et.al, 2009). This lack of statistics is reflective of the neglect shown to the plight of persons with disabilities on a general note in Nigeria. It may equally explain why there is lack of planning and policy implementation aimed at addressing issues related to their education, much less the provision of library services. Ajogwu's (2006) finding that the disadvantaged in Nigeria have inadequate library services and that libraries often fail to have specific, special provisions that encourage the blind students to use the library paints a succinct picture of the situation.

Libraries and information centers around the world have developed specialised information services to meet the library and information needs of their visually impaired clientele which include, Braille books, which is a system of reading and writing whereby raised dots are used to represent letters which are read by touch; Talking books, which are audio versions of books that could be recorded on cassettes, CD-ROM, DVD and on the internet as e-books and are preferred by majority of the visually impaired; Talking newspapers; Large printed materials in form of documents printed in large fonts for use by partially sighted users; and Electronic Texts, in form of computer text-files (Rayini, 2017). Also, libraries are taking advantage of advances in ICTs to increase information access for the visually impaired using a broad range of ICTs otherwise called adaptive or assistive technologies which are now available to provide access to information in electronic databases and on the internet, giving blind users equal opportunity as the sighted. These innovative technologies include: Screen magnifier, Screen reader, and Voice recognition software.

As at present, the National Policy on Education in Nigeria has no specific provisions on standards for library service provision for secondary school students with visual impairment even though it has provisions for secondary school education on a general note; neither does the Nigerian Library Association (NLA) and Nigerian School Library Association, which is its arm, nor the Librarians Registration Council of Nigeria, which is the supervisory body for librarians practicing in Nigeria. For this reason, inclusive education school libraries in Nigeria have no minimum standards to implement and no basis on which they are to be supervised and judged for 
effectiveness. This wide-scaled unresponsiveness towards meeting the information needs of students with visual impairment in school library media centres is in sharp contrast to the call by Emeagwali (2000) as cited by Oyegade (2003) that all Nigerians must learn to read and continue their education in libraries in order to catch up with the world, be part of the information age, become politically aware, and have capacity to claim their rights and become useful to the society. One may then wonder what level of library service and media-format availability that exist for students with visual impairment in secondary schools when this general anomalous situation has extrapolated them, together with already stated lack of specific policy guidelines for them. It is also interesting to imagine the level of satisfaction of students with visual impairment with the school library media centres service delivery in meeting the information needs of this category of students.

In view of this fact, Kassim \& Maduagwu (2006) recommend the provision of books-on-tape, large print books, books on braille, information and communication technologies (ICTs), tape recorders as well as the consideration of access to buildings which involves the provision of obstacle free routes with handrails and sizable door width, when providing library services for persons with visual impairment. This special nature of their resources, is deemed as contributory to their scarcity in most libraries vested with the responsibility to serve them, but cannot not be taken as a valid alibi for the service failure.

Because of their peculiarities of being either totally sightless or partially sighted, the mediaformats used to satisfy the information needs of persons with visual impairment differ in format. The provision of media-formats has to be done taking cognisance of the fact that their handicapping condition makes it impossible for them to read 'ink print' that is usually on paper. The media-formats used in serving the information needs of the persons with visual impairment have to be produced for use in line with two other senses of perception, which are those of touch and hearing. Other media-formats such as talking books, tapes, compact discs and DVDs are utilized by the persons with visual impairment through exercising their auditory sense, while

International Association of School Librarianship https://www.iasl-online.org/ 
most Digitally Accessible System (DAISY) materials are utilized through a combination of both senses of touch and hearing. The provision of these resources in libraries serving the persons with visual impairment cannot be compromised if their information needs are to be met.

Accessibility to the entire library services, media-formats, equipment for media-format utilisation and locations within the library is of a great significance in satisfying the information needs of persons with visual impairment due to their handicapping situation and special needs in information provision. Persons with visual impairment have long suffered exclusion in the provisions made indifferent types of libraries to satisfy the needs of users, through service and structural designs that do not factor in their peculiarities as reported by scholars in the literature. Persons with visual impairment need to have access to all services, resources and locations in the library that will contribute in meeting their information needs, and use them effectively as well. Accessibility therefore, is not merely reaching what is needed. It is a combination of reach, ability to use and efficient use of the services, media-formats and equipment for media-format utilisation in the libraries by persons with visual impairment, in the quest for satisfying their information needs.

Past studies such as (Idowu, 2005; Whitmire, 2006; Ugwu, 2009; and Ibenne, 2016) have indicated that a relationship exists between type and quality of library services and frequency of library use, user-satisfaction or user-frustration. In their view, while usersatisfaction leads to increased use of the library, user-frustration engenders anxiety and reluctance in the use of the library. It is obvious than when the service delivery conditions give room for library users to suffer these vices, user-satisfaction will be difficult to achieve, whereas user-satisfaction is the essence of all libraries.

Persons with visual impairment have a right to user-satisfaction in libraries. They have the right to exist in the society without discrimination, lead normal lives and fulfil their potentials, and this includes the fledging youths with that condition in secondary schools. They have information 
needs which when met will enable them to be fully integrated into the society and maximise their potentials. The burden of meeting their information needs rest majorly with their school library media centres. Achieving this goal will contribute in allaying the fears raised by Bello \& Adeleke (2009) that people with impairments are at a social disadvantage in Nigeria and also, lower the negatives in Haladu's (2007) objection to the fact that people with disabilities are victimised by neglect, superstition, inaccurate stereotyping, and exploitation with cultural beliefs about disabilities in Nigeria including shame, prejudice and exclusion from community.

It is in the light of the foregoing that this study investigated the extent to which library services, media-formats availability and accessibility affect the user-satisfaction of secondary school students with visual impairment in Ibadan, Oyo State, Nigeria.

The study focuses on library services, media-formats availability and accessibility as predictors of user-satisfaction among secondary school students in Oyo State. Institutions selected for the study excluded rehabilitation centres and vocational training centres which usually have a mixture of literate and illiterate persons and where library services are not often provided. The participants in this study included students in secondary schools established to cater for the visually impaired students in Oyo State, Nigeria. The study seeks to provide data for policy formulation to the administrators of the libraries/institutions that are established to meet the information needs of the secondary school students with visual impairment in South-Eastern Nigeria with reference to the improvement on quality and effectiveness of such information service in the various institutions. The study is expected to provide empirical evidence on the state of library service, media-format availability and accessibility to secondary school students with visual impairment in SouthEastern Nigeria. This will help all stakeholders involved in library and information service delivery to them to galvanize efforts towards improving on any deficiency unveiled by the study. The study is expected to stimulate the preparation and implementation of a National Policy on the provision of library and information service on a general scale for secondary school students with

International Association of School Librarianship https://www.iasl-online.org/ 
visual impairment in Nigeria. Such a policy document is presently non-existent and which possibly accounts for reported poor quality of service, lack of standards and the lack of coordination nationally in library service provision for this group of persons with visual impairment in Nigeria. Finally, the report from the study is expected to encourage librarians and other information professionals serving the needs of secondary school students with visual impairment to improve on the quality of services, media-formats and access rendered to them, thereby facilitating the formulation of a positive attitude towards library use by these students and engendering user-satisfaction.

The following research questions were posed for the purpose of achieving the objective of this study:

1. What are the information needs of students with visual impairment in Oyo State, Nigeria?

2. What are the library services and media-formats provided for students with visual impairment in Oyo State, Nigeria?

3. How accessible are library services and media formats for students with visual impairment in Oyo State, Nigeria?

4. What is the purpose of library use among students with visual impairment in the in Oyo State, Nigeria?

5. What relationships exist among information needs, library services, media-formats availability, accessibility, library use and among students with visual impairment in Oyo State, Nigeria?

6. What are the impediments to effective library use and user-satisfaction among students with visual impairment in Oyo State, Nigeria?

7. What is the joint contribution of Information needs, library services, media-format availability and accessibility to use of the school library media centres by students with visual impairment in Oyo State, Nigeria? 
8. To what extent do information needs, library services, media-formats availability and accessibility predict use of the school library media centres by students with visual impairment?

\section{Literature Review}

Visual impairment has received considerable attention by scholars, who have attempted to proffer various definitions, characterisations and causes. Beverly, Bath \& Barber (2011) highlighted many different types and causes of visual impairment to include glaucoma, cataracts and detached retina. According to them, the age at which people first experience visual impairment ranges from birth to advanced old and that visual impairment is also frequently experienced along with other disabilities or illness, some of which might be permanent, such as arthritis, heart conditions, mobility problems, diabetes and hearing impairment. Therefore, people with visual impairment are often regular users of health and social care services, due either to the visual impairment itself, or due to comorbidities.

Persons with visual impairment have been broadly grouped into the blind, partially sighted, and those with low-vision (Nnadozie, 2006; Ojebode, 2003 and Kanu, 2003). In his definition, Osinuga, (2003) states that they are persons who exhibit some amount of visual inadequacies, those whose vision is severely defective and those who have no sight at all and by implication, are people who require the use of special means to perceive what people normally and naturally see.

Visual impairment has been attributed to various causes some of which Saha, Bhowmick and Sinha (2009) articulated as central field loss (CFL), where the central retina is damaged by macular degeneration; diabetic retinopathy and other diseases which are also responsible for CFL; damage of the natural retinal locus of high resolution vision (the fovea); and, diseases like central scotoma and cataracts. The World Health Organization (2012) attributed the principal causes of visual impairments to uncorrected refractive errors and cataracts with $43.0 \%$ and $33.0 \%$ rates respectively. Other causes listed were glaucoma, $2 \%$, age related macular degeneration (AMD), diabetic retinopathy, trachoma and corneal

International Association of School Librarianship https://www.iasl-online.org/ 
opacities, all about 1\%, and a large proportion of other causes labelled as undetermined, $18 \%$.

Specifically on blindness (total and absolute loss of vision), the WHO further listed its causes as cataract, $51.0 \%$, glaucoma, $8.0 \%$, AMD, 5.0\% childhood blindness and corneal opacities, $4.0 \%$, uncorrected refractive errors and trachoma, $3.0 \%$, and diabetic retinopathy, $1.0 \%$, with the undetermined causes as 21.0\%. A study by Abdull, Sivasubramaniam, Murthy, Gilbert, Abubakar, Ezelum, \& Rabiu, (2009) reveals that in Nigeria, $84.0 \%$ of blindness were either preventable or treatable and that trachoma, glaucoma and cataract were responsible for a significant proportion of blindness in different areas of the country.

An IFLA (1999) report revealed that most students with visual impairment find that they need some type of device to help them to be effective learners in school settings, such as large-print materials, specialised magnification lenses, or electronic enlargement for assistance. In recognition of the special needs of the visually impaired, IFLA created a section called 'Libraries Serving Persons with Print Disabilities Section', previously called 'Libraries for the Blind Section', with their main purpose of being able to promote national and international cooperation and to encourage research and development thus improving the access of information for the blind and other people with print disabilities. Therefore, it is expected that libraries, whether within institutions, public or private need to adopt inclusive practices that will enable them extend their services to exceptional categories especially those with visual impairment. Services and programs that meet the needs of the visually impaired include the necessity for communication to be clear and understandable, for patrons to feel welcome, to remove all physical and psychological barriers inhibiting users from entering the library to communicate their needs. A reading service could also be offered featuring articles and other short texts read into a sound medium or scanned into a computer. Equally inclusive are regularly scheduled consultations with staff designated specifically to serve the needs of the visually impaired (Nielsen \& Irvall, 2005).

Also, library services constitute an effective means of helping the sightless to resume a full existence and encouraging them to undertake socially useful work as far as their psychological and physiological limitations permit. This is why Ekwelem (2013) advocated a library service for the visually impaired students as a specially organised system that differs in many ways from library service to sighted students and that in order to render library service to visually handicapped students as efficiently as possible, it is important to decide to what extent existing library systems can render the readers full service; whether new, specially organised systems have to be established and whether the best solution might not be to 
establish specially organised library systems for the visually handicapped readers. Hence, the need for inclusiveness.

Inclusive education is a method adopted in educational circles to circumvent the perceptions of segregation and isolation that people with challenges seem to be subjected through special schools. In Omotayo (2010) view, inclusive education is about the participation of all children and young people as well as the removal of all forms of exclusionary practice, and further asserts that inclusive education implies that existing school systems in terms of physical factors, curriculum aspects, teaching expectations and styles will have to change.

On its part, UNESCO (2003) notes that inclusion as a developmental approach that seeks to address the learning needs of all children, youths and adults with a specific focus on those who are vulnerable to marginalization and exclusion. It further suggests that inclusive education means that schools should accommodate all children regardless of their physical, intellectual, social, emotional, linguistic or other conditions. In the same vein Atinmo (2012) avers that the notion of inclusion shows the imperatives of providing equal access to information to persons with visual impairment because of the dynamism of the present day information environment and the need for everyone to be included. However, the arguments in favour of inclusion does not suggest that everyone agrees with it. There are many who still favour the special system as better for those with disabilities.

Unlike in the past, there are now many more persons with visual impairment in secondary and tertiary institutions who need reading and educational materials in alternative formats (Atinmo, 2012). This assertion brings to focus the need to provide school library services, media-formats and the sort of access that will enable visually impaired students become effective users of the library. This is because free library service is a component of the foundations of democracy, citizenship, economic and social development, scholarship and education, in progressive societies (Steer \& Cheetham, 2005).

The use of libraries is closely linked to information needs satisfaction. Uhegbu's (2001) assertion that every human being needs information, and that our information needs are bound to our cosmology of life

International Association of School Librarianship https://www.iasl-online.org/ 
supports the fact that library users are of various types and with differing characteristics. In the view of Suamure \& Given (2004) blind and partially sighted post-secondary students must access the materials that they need for their studies in the context of their disability. That is, because these students are unable to use traditional print materials, they are forced to locate alternative means of accessing academic information. The non-traditional formats (e.g. Braille) that visually impaired students require are not as readily available as are print formats. Citing CNIB (2004), they argue that less than 5\% of print materials are available in alternative format. This leaves these students marginalized in their quest for information, compared to their sighted peers. It may not appear a bogus claim to suggest that this situation applies equally to students with visual impairment at the secondary school level.

\section{Theoretical Underpinnings}

This study was anchored on the Universal Design and Access Theory. The theory was proposed by Herriot (2006) and posits seven characteristics that make designs for libraries universally accessible, which are: equitable use; flexibility in use; simple and intuitive use; perceptible information; tolerance for error; low physical effort; and, size and space for approach and use. According to him, the universal design starts with a focus on inclusion for all users, and envisages that the overall usability of an environment or product is increased without adding unnecessarily to redesign cost. In his view, a universal design approach avoids the pitfalls of implementing segregated accessibility features that are often viewed as "special" and that within library service environment, using a universal design approach allows for the greatest level of flexibility.

The universal design approach presents a broad-based framework for providing an inclusive, nonsegregated library service, which takes care of the needs of all library patrons. It pre-supposes that from inception, the library takes into consideration the provision of the kind of services that effectively takes care of the needs of persons with visual impairment. Universality thus entails a library service that is flexible to accommodate varied interests of all users, and has a good tolerance for error from all users, particularly the visually impaired persons. It is on this note that the library service is considered as equitable. 
The characteristics of simple and intuitive use and perceptible information contained in the theory, relate to the provision of information to the visually impaired persons with the appropriate media-formats. The literature indicates that when media-formats appropriate in serving the needs of the persons with visual impairment are used, their perception of information is made faster, easier and generally intuitive for them since their sense adaptation, as a consequence of loss of sight, is tailored towards the perception of information through alternative formats to print.

The characteristics of equitable use, flexibility in use, low physical effort size and space for approach and use addresses the third independent variable which is accessibility. Accessibility to the information resources, equipment and locations within the library housing needed resources and/or services must be guaranteed for the persons with visual impairment. This is because their right to have uninhibited access to any needed service or resource must be upheld in the provisions made by the library, in order to ensure that the principle of universality is practiced.

\section{Methodology}

The study adopted the survey method of the ex-post facto type. Survey researches are deemed useful in conducting researches that are based on eliciting opinions from groups of persons. The population of the study comprise 84 students with visual impairment who spread across the 4 designated schools for their category. The schools covered by the study are; School for the Deaf and Blind, Eruwa (22); School for the Blind, Aperin Oniyere, Ibadan (08), School for the Blind, Durba, Oyo Town (13) and Ogbomosho Training Centre for the Blind, Ogbomosho (41) (Ministry of Education, Oyo State, 2017). The total enumeration method was used to include all the 63 visually impaired students in the designated schools as respondents for the study. The instrument used in collecting data for this study is a questionnaire. The questionnaire which comprises six sections was used to elicit responses from the students with visual impairment in the schools surveyed. Section A of the questionnaire was designed to elicit information on the demographic background of the respondents while section B focussed on assessment of library services for the students. Sections C, D, E and F of the questionnaire was designed to collect data on assessment of media-format utilisation, media formats availability, accessibility and library use respectively. In validating the instrument, the questionnaire was given to experts in the field of Library,

International Association of School Librarianship https://www.iasl-online.org/ 
Archival and Information Studies and Special Education at the University of Ibadan for criticism in order to ascertain their face and content validity. Based on criticism and suggestions by the experts, corrections and amendments were made on the questionnaire to ensure its ability to elicit reliable data and measuring what they purport to measure.

The trial testing-testing of the instruments for reliability was done by administering the questionnaire on 10 students of Ondo State School for the Blind Ondo. The reliability of the instruments was determined using the Cronbach Alpha Coefficient which yielded coefficient values of 0.88, 0.90, 0.86, 0.89 and 0.79 respectively for assessment of mediaformat utilisation, media formats availability, accessibility and library use scales respectively.

The questionnaire which was in braille format was administered to the visually impaired students by the researcher with the assistance of 2 trained research assistants. The researcher worked with the assistance of the special education teachers in the process of gathering data from the schools. The eliciting of data entailed the students typing their responses for the researcher. Those who did not type put their responses in braille which was transcribed back into the ink-print version of the questionnaire by the researcher with the assistance of a braille specialist at Federal College of Education (Special), Oyo, Oyo State.

The descriptive methods of analysis and inferential statistics were used in analysing the data collected for the study. Research questions 1 to 4 (RQ1.RQ4) and research question 6 (RQ6) were analysed using descriptive method of analysis such as frequency counts percentages, mean and standard deviation while research question 5 (RQ5) was answered using pearson product of moment correlation while research questions 7 and 8 were 15 answered using multiple regression technique. The hypotheses were tested using multiple regression technique at 0.05 level of significance.

\section{Data Analysis and Discussion of Findings}

Out of the total of 73 visually impaired students spread across the four designated schools, only 54 students participated in this study. This gives a response rate $73.9 \%$. Other students were not available and not reachable during the five weeks periods of collecting data for the study. 


\section{Background Information}

The background information of the students with visual impairment revealed that there are more totally blind persons $42(77.8 \%)$ than partially blind persons among the respondents for the study. This is in contrast with the global data on blindness by the World Health Organization (2012) which revealed a greater percentage of people with partial sightedness than totally blind persons. Reasons for this disparity may be attributed to the finding of Abdull et.al (2009) that most conditions leading to blindness are preventable, but many people in Nigeria do not seek early ophthalmological intervention due to issues related to socio-economic conditions, socio-demographic conditions and illiteracy.

The distribution of the students with visual impairment based on gender revealed that there are more female $41(75.9 \%)$ than male with visual impairment 13 (24.1\%) among the respondents. This implies that there are more female students than male with visual impairments in the schools surveyed. This is in contrast with the findings of Fasina and Ajaiyeoba (2003) and Adegbehinde, Fajemilehin and Bisiriyu (2006) cited by Adetoro (2008) that visual impairment occurred twice as much in men than women in Osun State, Nigeria. This variance in result may be partly attributed to the increased enrolment of girlchid in schools as a result of campaign for girl-child education in Nigeria. Another explanation may be traced to Ezepue's (1997) view that the prevalence and causes of blindness are known to vary from place to place depending on such variables as time and season, culture, socio-economic conditions, climate and other diverse environmental and genetic conditions.

Also, the age distribution of the respondents revealed that majority of the students with visual impairment $44(81.5 \%)$ were within the age range of 16-25 years while only few of the students with visual impairment were within the age range of 25 years and above. This finding corroborates the view of Ibenne (2016) that blindness has a grave socioeconomic implication and that of Bello and Adeleke (2009) that people with impairments are at a social disadvantage in Nigeria. It is therefore possible that it is this social disadvantage which is created by non-provision of services, social care and amenities that culminates in either their late entry to the secondary schools or their delayed progression due to academic performance.

International Association of School Librarianship https://www.iasl-online.org/ 
Furthermore, the background information of the students revealed that majority of the respondents 41 (75.9\%) became visually impaired after starting school (See Appendix 1, Table 1). The major causes of visual impairment among the students were found to be diseases 20 (37.0\%) and accident 20 (37.0\%) (See Appendix 1, Table 2). Glaucoma 19 (35.2\%) and Playground accident 20 (37.0\%) were found to be the major type of disease and accident that cause visual impairment among the students respectively (See Appendix 1, Tables 3 and 4). Majority of the visually impaired students 43 (79.6\%) were found to have started the use of Braille from primary school. (See Appendix 1, Table 5).

Research question 1: What are the Information needs of the students with visual impairment in the schools surveyed in Oyo State, Nigeria?

Table 1: Information Needs of secondary school students with visual impairment

\begin{tabular}{|l|l|l|}
\hline Information Needs & Frequency & Percentage \\
\hline Information needed to pass my examinations & 49 & 90.7 \\
\hline Information on Educational opportunities & 48 & 88.9 \\
\hline Information on coping with my visual impairment & 39 & 72.2 \\
\hline Information for completion of assignments & 37 & 68.5 \\
\hline Health information & 37 & 68.5 \\
\hline Information on library use & 34 & 63.0 \\
\hline Information on current ICT trends & 34 & 63.0 \\
\hline Information on Career choices and vocation & 25 & 46.3 \\
\hline Information on Current affairs and politics & 22 & 40.7 \\
\hline Information on Conferences & 9 & 16.7 \\
\hline Information on Travel information/tourism & 9 & 6.7 \\
\hline Information on sports and recreation & 3 & 5.6 \\
\hline Information on my subjects of interest & 2 & 3.7 \\
\hline $\begin{array}{l}\text { Information on fiction books/other relaxation } \\
\text { literature }\end{array}$ & - & - \\
\hline
\end{tabular}


Table 1 presents the information needs of the students with visual impairment and it reveals the major information needs of the students to include, information needed to pass examinations $(49,90.7 \%)$, information on educational opportunities $(48,88.9 \%)$, information on coping with visual impairment (39, $72.2 \%$ ), information on completion of assignments $(37,68.5 \%)$ and health information $(37,68.5 \%)$. Other information needs prominent among majority of the visually-impaired students are information on library use $(34,63.0 \%)$, and information on current ICT trends $(34,60.5 \%)$. The implication to be drawn from the above information is that the major information needs of the visuallyimpaired students in persons are basically in the areas of educational information, health information and information on coping with their visual impairment. This is in conformity with the report of IFLA (2006), Kassim \& Maduagwu, (2006) and Atinmo, (2012) who all agree that students with visual impairment need effective information service in as a basis for achieving academic excellence and for managing other aspects of their lives and to achieve integration into the society.

Research question 2: What are the library services and media formats provided for the students with visual impairment in the schools surveyed in Oyo State, Nigeria?

Table 2: Library Services and Media Format Availability for Students with Visual

\begin{tabular}{|l|l|l|}
\hline Service & Available & Not Available \\
\hline Reading service for short materials & $42(77.8 \%)$ & $12(22.2 \%)$ \\
\hline $\begin{array}{l}\text { Designated staff for services to students with } \\
\text { visual impairment }\end{array}$ & $42(77.8 \%)$ & $12(22.2 \%)$ \\
\hline Volunteers who help to record books on tape & $39(72.2 \%)$ & $15(27.8 \%)$ \\
\hline $\begin{array}{l}\text { Computers equipped with screen reading and } \\
\text { synthetic speech }\end{array}$ & $36(66.7 \%)$ & $18(33.3 \%)$ \\
\hline $\begin{array}{l}\text { Trained staff who are able to communicate } \\
\text { understandably }\end{array}$ & $33(61.1 \%)$ & $21(38.9 \%)$ \\
\hline $\begin{array}{l}\text { Scheduled consultations with the designated } \\
\text { staff }\end{array}$ & $26(48.1 \%)$ & $28(51.9 \%)$ \\
\hline
\end{tabular}

International Association of School Librarianship https://www.iasl-online.org/ 


\begin{tabular}{|l|l|l|}
\hline Material delivery by mail & $8(14.8 \%)$ & $46(85.2 \%)$ \\
\hline $\begin{array}{l}\text { Guided tours for familiarization with the } \\
\text { library }\end{array}$ & $8(14.8 \%)$ & $46(85.2 \%)$ \\
\hline Braille production/transcription service & $7(13.0 \%)$ & $47(87.0 \%)$ \\
\hline $\begin{array}{l}\text { Information booklets in alternative media } \\
\text { formats }\end{array}$ & $4(7.4 \%)$ & $50(92.6 \%)$ \\
\hline Recording studio service & - & $54(100.0 \%)$ \\
\hline $\begin{array}{l}\text { An organized queue system in all library } \\
\text { service points }\end{array}$ & - & $54(100.0 \%)$ \\
\hline
\end{tabular}

The result as shown in Table 2 provides the response of the students with visual impairment on library services in their schools. It revealed that majority of the students attested to the provision of reading service 42 (77.8\%), designated staff service 42 (77.8\%), volunteers' service 39 (72.2\%), computers, screen reading and synthetic speech service $36(66.7 \%)$ and interpretation and translation service 33 $(61.1 \%)$ in their libraries. It can, therefore, be inferred that circulation service, reference service and screen reading service on computers are library services commonly provided for in the school library media centres in the surveyed schools. The availability of some of the required services reflects an understanding by these libraries of the notion of special care in libraries for persons with visual impairment as posited by Ogbaa (2000), Atinmo (2000) and Nielsen and Irvall (2005). However, the absence of majority of the needed services, is in line with Ajogwu (2006) who holds that the disadvantaged in Nigeria have inadequate library services. A likely explanation may come from Oyegade (2000) who argues that most libraries in Nigeria are grossly underfunded and neglected to be able to play their roles effectively.

\section{Table 3: Media Format Availability for Students with Visual Impairment}

\begin{tabular}{|l|l|l|l|}
\hline Media Format & Available & $\begin{array}{l}\text { Not Readily } \\
\text { Available }\end{array}$ & Not Available \\
\hline Talking books/books on tape & $9(16.7 \%)$ & $7(12.9 \%)$ & $20(37.3 \%)$ \\
\hline Large print books/magazines & $14(25.9 \%)$ & $2(3.7 \%)$ & $34(62.9 \%)$ \\
\hline Braille books & $13(24.1 \%)$ & - & $36(66.7 \%)$ \\
\hline Braille-in-print & $13(24.1 \%)$ & $6(11.1 \%)$ & $18(33.3 \%)$ \\
\hline
\end{tabular}




\begin{tabular}{|l|l|l|l|}
\hline $\begin{array}{l}\text { E d u c a ti o n a l r a d i o / T V } \\
\text { programmes }\end{array}$ & $9(16.7 \%)$ & $7(12.9 \%)$ & $21(38.9 \%$ \\
\hline Tactile picture books & $7(12.9 \%)$ & $8(14.8 \%)$ & $16(29.6 \%)$ \\
\hline DAISY reading software/materials & $9(16.7 \%)$ & $4(7.4 \%)$ & $20(37.0 \%)$ \\
\hline Talking magazines/journals & - & $5(9.3 \%)$ & $31(57.4 \%)$ \\
\hline Videos/DVD books & - & $11(20.4 \%)$ & $22(40.7 \%)$ \\
\hline
\end{tabular}

On media-format availability, Table 3 revealed a low-level of media format availability for students with visual impairment in the school library media centres surveyed. Large Print Books/Magazines 14 (25.9\%), Braille Book 13(24.1\%) and Braille-in-Print 13(24.1\%) were found to be prominent among the few media-format available for the students in the libraries. Other media-format available as attested to by only few of the respondents include Taking Books/Books on Tape 9 (16.7\%), Educational Radio/TV programmes 9(16.78\%), Daisy Reading Software/Materials 9 (16.7\%) and Tactile Picture Books 7 $(12.9 \%)$. The inference to be drawn from this is that there is a dearth of mediaformats adequate in meeting the information needs of students with visual impairment in the libraries of the schools studied in Oyo State, Nigeria. This result depicts a grossly inadequate level of media-format availability in the selected libraries, reflecting a gulf of difference with reports in other countries, Klinkosz, Sekowski and Brambring (2006), Ratna (2007) and Steer and Cheetham (2005), reporting the cases in Poland, India and Australia respectively. In Poland particularly, the success rate in the support of the students with visual impairment with adequate resources was such that enabled $20 \%$ of them to progress to higher institutions. It is equally appalling that in an era where most information resources, including those for the visually impaired are going more digital than print-based (Keefer, Kakumanu and Boubakis, 2009; Beverly, Bath and Barber, 2011), the school libraries in Oyo State schools for the visually impaired are still burdened with inadequate availability of paper-based braille. In this circumstance, it becomes very doubtful that they can effectively serve the information needs of the students.

Research question 3: How accessible are library services and media formats to students with visual impairment in in Oyo State, Nigeria?

International Association of School Librarianship https://www.iasl-online.org/ 
Table 4: Library Services and Media Formats Accessibility to students with visual impairment in Oyo State, Nigeria.

\begin{tabular}{|c|c|c|c|c|}
\hline Statement & $\begin{array}{l}\text { Strongly } \\
\text { Disagree }\end{array}$ & Disagree & Agree & $\begin{array}{l}\text { S t rong l y } \\
\text { Agree }\end{array}$ \\
\hline $\begin{array}{l}\text { The circulation desk is very } \\
\text { easy to reach }\end{array}$ & $5(9.3 \%)$ & $\begin{array}{ll}3 & 8 \\
(70.4 \%) & \end{array}$ & $9(16.7 \%)$ & $2(3.7 \%)$ \\
\hline $\begin{array}{l}\text { The entrance stairs are easily } \\
\text { accessible }\end{array}$ & $2(3.7 \%)$ & $\begin{array}{l}41 \\
(75.9 \%)\end{array}$ & $\begin{array}{l}1 \\
(20.4 \%)\end{array}$ & - \\
\hline $\begin{array}{l}\text { I have access to library staff } \\
\text { whenever I need their help }\end{array}$ & $4(7.4 \%)$ & $\begin{array}{l}39 \\
(72.2 \%)\end{array}$ & $\begin{array}{l}1 \\
(20.4 \%)\end{array}$ & - \\
\hline $\begin{array}{l}\text { My right to borrow library } \\
\text { materials is guaranteed }\end{array}$ & $8(14.8 \%)$ & $\begin{array}{ll}2 & 5 \\
(46.3 \%) & \end{array}$ & $\begin{array}{l}1 \\
(26.0 \%)\end{array}$ & - \\
\hline $\begin{array}{l}\text { The library has smooth non-slip } \\
\text { surfaces that makes me } \\
\text { confident I will not fall }\end{array}$ & $\begin{array}{l}1 \\
(1.9 \%)\end{array}$ & $\begin{array}{ll}3 & 1 \\
(57.4 \%)\end{array}$ & $\begin{array}{l}1 \\
(31.5 \%)^{7}\end{array}$ & $5(9.3 \%)$ \\
\hline $\begin{array}{l}\text { There are paths sounders to } \\
\text { warn me of protrusions, walls to } \\
\text { guide me movement around }\end{array}$ & $2(3.7 \%)$ & $\begin{array}{ll}3 & 0 \\
(55.6 \%)\end{array}$ & $\begin{array}{l}1 \\
(29.6 \%)^{6}\end{array}$ & $6(11.1 \%)$ \\
\hline $\begin{array}{l}\text { The library has embossed/ } \\
\text { brailed signs which can be read } \\
\text { by touch }\end{array}$ & $2(3.7 \%)$ & $\begin{array}{ll}2 & 1 \\
(38.9 \%)\end{array}$ & $\begin{array}{l}2 \\
(53.7 \%)\end{array}$ & $2(3.7 \%)$ \\
\hline $\begin{array}{l}\text { I have unrestricted access to } \\
\text { information resources/media } \\
\text { formats }\end{array}$ & - & $\begin{array}{ll}2 & 8 \\
(51.9 \%)\end{array}$ & $\begin{array}{l}2 \\
(38.9 \%)\end{array}$ & $5(9.3 \%)$ \\
\hline $\begin{array}{l}\text { It is easy to find my way around } \\
\text { the library }\end{array}$ & $3(5.6 \%)$ & $\begin{array}{ll}3 & 7 \\
(68.5 \%)\end{array}$ & $4(7.4 \%)$ & \\
\hline $\begin{array}{l}\text { I am familiar with the } \\
\text { arrangements of fittings and } \\
\text { furniture in the library }\end{array}$ & $3(5.6 \%)$ & $\begin{array}{ll}2 & 5 \\
(46.3 \%) & \end{array}$ & $\begin{array}{l}1 \\
(24.1 \%)^{3}\end{array}$ & $13(24.1 \%)$ \\
\hline Weighted Mean & & & & \\
\hline
\end{tabular}


Table 4 presents information on accessibility to library services and media formats by students with visual impairment and it revealed that majority of the respondents disagreed with many of the statements that support ease of access to library service. For instance, majority of the respondents attested to the lack of ease of accessing the circulation desk 43 (79.7\%), lack of ease of accessing the entrance stairs 43 (79.7\%), lack of access to library staff whenever they need help 43 (79.7\%) and lack of ease of finding their way around the library $40(74.1 \%)$. Moreover, majority of the respondents attested to the fact that there is lack of guaranteed borrowing privileges within the library $33(61.1 \%)$, lack of path sounders to guide their movement around the library 32 (59.3\%), lack of smooth non-slip surfaces to prevent fall 32 $(59.3 \%)$, lack of unrestricted access to information resources media-format 28 (51.9\%), and lack of familiarity with the furniture and fittings in the library 28 (51.9\%). This implies a low level of library service and media formats accessibility by the students with visual impairment in Oyo State, Nigeria. Findings from this study is in line with results IFLA (2005), Gibson, (2006), John-Okeke, (2006), Ajogwu, (2006) and Ekwelem, (2013) who hold the collective view that access granted to persons with visual impairment in many school library media centres is poor, inadequate and to a good degree insensitive to the condition of the visually impaired students. Also, Beverly, Bath and Barber (2011) held the view that information is not always accessible to or appropriately packaged for persons with visual impairment in the right format, at the right time, or in sufficient detail, whereas John-Okeke (2006) sees accessibility as a vital element in information utilisation, this scenario is capable of eliciting the negative feelings of frustration, leading to user-dissatisfaction with school library media centres in their school.

Research question 4: What is the purpose of library use among students with visual impairment in Oyo State, Nigeria?

International Association of School Librarianship https://www.iasl-online.org/ 
Table 5: Students with visual impairment Response on Purpose of Library Use

\begin{tabular}{|l|l|l|}
\hline Purpose of Library Use & Frequency & Percentage \\
\hline Using of talking books & 21 & 38.9 \\
\hline $\begin{array}{l}\text { Reading of educational braille } \\
\text { materials }\end{array}$ & 39 & 72.2 \\
\hline To read for examinations & 34 & 63.0 \\
\hline To complete my class assignments & 37 & 68.5 \\
\hline To relax with friends & 26 & 48.1 \\
\hline Reading of fiction/relaxation literature & 11 & 20.4 \\
\hline To use Internet chat/social networks & 4 & 7.4 \\
\hline To search databases & 3 & 5.6 \\
\hline To escape boredom & 6 & 11.1 \\
\hline To browse the Internet & - & - \\
\hline To use e-mail service & - & - \\
\hline
\end{tabular}

The major purposes of use of library by the students with visual impairment as revealed by Table 5 include: reading of educational Braille materials 39 (72.2\%), to complete class assignments 37 (68.5\%), reading for examinations $34(63.0 \%)$ and using of talking books 21 (38.9\%). The implication to be drawn from this is that the visually impaired students in Oyo State use the library mainly for educational purposes. This finding agrees with the report of IFLA (2005), which states that students with visual impairment need the provision of learning resources and environment in school library media centres to support their process of their education and recommended its provision as a matter of urgency.

Table 6: Students with visual impairment response on frequency of library use

\begin{tabular}{|l|l|l|}
\hline Response & Frequency & Percentage (\%) \\
\hline Daily & 32 & 59.3 \\
\hline Two/Three times a week & 8 & 14.8 \\
\hline Once in two weeks & 3 & 5.6 \\
\hline Once in a month & 11 & 20.4 \\
\hline
\end{tabular}


Table 6 revealed a regular use of library by majority of the visually impaired students in Oyo State with the responses for daily and two/three times a week having a combined $40(74.1 \%)$ response rate. This result corroborates Atinmo, Maduagwu (2006) and Ibenne (2016) findings which established regular use of library by visually impaired students and attributed the use of libraries by persons with visual impairment to their desire to satisfy their information needs, much in the same way that persons with sight satisfy their information needs.

Research question 5: What relationships exist among information needs, library services, accessibility, media formats availability and library use by students with visual impairment in Oyo State?

Table 7: Summary of relationships among the variables of study

\begin{tabular}{|l|l|l|l|l|l|l|l|l|l|}
\hline Variables & $\mathbf{N}$ & Mean & SD & $\mathbf{1}$ & $\mathbf{2}$ & $\mathbf{3}$ & $\mathbf{4}$ & $\mathbf{5}$ & $\mathbf{6}$ \\
\hline Library Use & 54 & 6.26 & 1.803 & 1 & & & & & \\
\hline $\begin{array}{l}\text { In formation } \\
\text { Needs }\end{array}$ & 54 & -0.69 & 0.469 & .701 & .854 & 1 & & & \\
\hline $\begin{array}{l}\text { Library Service } \\
\text { Provision }\end{array}$ & 54 & 4.54 & 1.920 & .591 & .593 & .652 & 1 & & \\
\hline $\begin{array}{l}\text { Media format } \\
\text { availability }\end{array}$ & 54 & 10.52 & 7.578 & .031 & .216 & .307 & .456 & 1 & \\
\hline $\begin{array}{l}\text { Media format } \\
\text { accessibility }\end{array}$ & 54 & 25.67 & 4.937 & .521 & .644 & .394 & .222 & .084 & 1 \\
\hline
\end{tabular}

Sig $=\mathrm{p}<0.01$

Table 7 presents the detail of the relationships among the variables of study (that is information needs, library services, accessibility, media format availability, and library use by students with visual impairment). It can be deduced from the information on Table 7 that information needs $(\mathrm{r}=0.854, \mathrm{p}<$ $0.05)$, library service provision $(\mathrm{r}=0.591, \mathrm{p}<0.05)$ and media format $(\mathrm{r}=0.31, \mathrm{p}<0.05)$ are positively related to library use by students with visual impairment in designated schools in Oyo State, Nigeria. However, while information needs, library service provision, library service accessibility have strong 
positive relationships with library use media format availability was found to exhibit a very weak positive relationship with library use. Therefore, it can be inferred from the above information that the pattern of library use among the visually impaired students in Oyo State would increase with increased information needs, improved library service provision, media formats availability and accessibility. The findings agree with that of Akakandelwa and Munsanje (2012) in a study in Zambia. Media-format availability exhibited a weak positive relationship with library use, in contrast with the report of Iweha (2003) that the UK vision services which facilitated the availability of resources for persons with visual impairment in the United Kingdom encouraged a rise in library use among them.

Research question 6: What are the impediments to effective library use among students with visual impairment in Oyo State?

Table 8: Impediments to Library Use among the students with visual impairment

\begin{tabular}{|l|l|l|}
\hline Impediments & $\begin{array}{l}\text { Frequenc } \\
\mathbf{y}\end{array}$ & Percentage (\%) \\
\hline Unavailability of needed media formats & 42 & 77.8 \\
\hline Content of media formats & 39 & 72.2 \\
\hline Outdated media formats & 37 & 68.5 \\
Unavailability of equipment for media format use & 32 & 59.3 \\
\hline Inaccessibility of the media formats & 28 & 51.9 \\
\hline Dysfunctional equipment for media format use & 28 & 51.9 \\
\hline Lack of recording studio & 28 & 51.9 \\
\hline Atmosphere in the library not conducive & 17 & 31.5 \\
\hline Inaccessibility of locations within the library & 9 & 16.7 \\
\hline Unfriendliness attitude of the library staff & 8 & 14.8 \\
\hline Amount of time spent waiting for needed service & 28 & 51.9 \\
\hline Borrowing privileges not guaranteed & 31 & 57.4 \\
\hline Limited library opening hours & - & \\
\hline
\end{tabular}


Table 8 revealed unavailability of needed media formats $(42,77.8 \%)$, contents of media formats (39, $72.2 \%$ ), outdated media formats $(37,68.5 \%)$, unavailability of equipment for media format use (32, $59.3 \%)$, inaccessibility of the media formats $(28,51.9 \%)$, dysfunctional equipment for media format use $(28,51.9 \%)$, and lack of recording studio $(28,51.9 \%)$ as topping the list of impediments to library use by the respondents. This implies that unavailability of needed media formats, content of media formats, outdated media formats, unavailability of equipment for media format use, inaccessibility of the media formats, dysfunctional equipment for media format use and lack of recording studio are major impediments to library use by visually impaired students in designated schools in Oyo State.

Research question 7: What is the joint contribution of Information needs, library services, media-format availability and accessibility to use of the school library media centres by students with visual impairment in Oyo State, Nigeria?

Table 9: Test of Significance of Joint Contribution of Information needs, Library Services, Media Format Availability and Accessibility to Library Use by students with visual impairment

\begin{tabular}{|l|l|l|l|l|l|}
\hline Model & Sum of squares & df & Mean square & F & Sig \\
\hline Due to regression & 108.290 & 4 & 27.072 & 20.701 & .000 \\
\hline Due to residual & 64.081 & 49 & 1.308 & & \\
\hline Total & 172.370 & 53 & & & \\
\hline
\end{tabular}

$$
\mathrm{R}=.793, \mathrm{R}^{2}=.628, \text { Adj } \mathrm{R}^{2}=.598, \mathrm{SEE}=1.144
$$

Table 9 clearly shows that the joint contribution of information needs, library services, accessibility and media formats availability on the library use is significant. $(F(4,49)=20.70, p<0.05)$. This implies that the joint contribution of information needs, library service provision, library service accessibility and media formats availability on library use by the visually impaired students is significant. Furthermore, information needs, library services, accessibility and media format availability was found to have jointly accounted for $62.8 \%$ of the total variance in library use $(\mathrm{R} 2=0.628)$.

International Association of School Librarianship https://www.iasl-online.org/ 
Research question 8: To what extent do information needs, library services, mediaformats availability and accessibility predict use of the school library media centres by students with visual impairment?

Table 10: Model Summary of Level of Information needs, Library Services, MediaFormat Availability and Accessibility prediction of library use by the students with visual impairment

\begin{tabular}{|l|l|l|l|l|}
\hline Model & R & R Square & Adjusted R Square & $\begin{array}{l}\text { Std. Error of the } \\
\text { Estimate }\end{array}$ \\
\hline 1 & .701 & .491 & .482 & 1.299 \\
\hline 2 & .750 & .562 & .545 & 1.217 \\
\hline 3 & .773 & .598 & .574 & 1.177 \\
\hline
\end{tabular}

Predictors: (Constant), information needs.

Predictors: (Constant), information needs, accessibility to library service.

Predictors: (Constant), information needs, accessibility to library service, library service provision.

Dependent Variable: Library use

Table 10 presents information on the best predictors of library use among the independent variables of information needs, library service provision, library service accessibility and media format availability and it revealed information need, library service accessibility and library service provision as the predictors of library use by students with visual impairment. However, information needs was observed to be the best predictor of library use with a total contribution of $49.1 \%$ to the total variance in library use among students with visual impairment. Accessibility was observed to be the second best predictor of library use with a contribution of $7.1 \%$ only to the total variance in library use but together with information needs accounted for $56.3 \%$ of the total variance in library use among the students with visual impairment. The last predictor of library use was found to be library service provision that accounted for only $3.4 \%$ but together with information needs and library service accessibility accounted for $59.8 \%$ of the total variance in library use among the visually impaired students in the schools studied. The 
implication to be drawn from this is that information needs, library service accessibility, and library service provision are major predictors of library use among the secondary school students with visual impairment in the schools studied.

\section{Summary, Implication and Conclusion}

The study investigated the influence of library service factors and information needs of students with visual impairment on their library usage. The study revealed that students with visual impairment have specific information needs which were mostly educationally centred. They needed information specifically for passing examinations, finding educational opportunities, completion of assignments and library use. They also expressed information needs in other areas like coping with their visual impairment condition, health information, information on ICT trends and on career choices and vocation. Also, most of the library services needed by the students were not provided. The most deficient areas being braille production/transcription, recording studio service, guided familiarization with the library and material order and delivery.

Moreover, the media-formats provided in the school library media centres for the students with visual impairment were very inadequate, with large print materials, braille-in-print, talking books/magazines, DVDs, tactile picture books, recorded educational radio/TV programmes being more severe while accessibility to the media-formats and library services for the students with visual impairment is poor. The purpose of use of their school library media centres by the students with visual impairment was educationally centred but also diverse just as a regular use of their school library media centres among the students with visual impairment was established. Library services and media-format availability do not have significant positive influence on library usage by students with visual impairment while a significant joint positive contribution of information needs, library services, and accessibility on library usage among the students with visual impairment was established.

The level of use of library by the students with visual impairment will be increased by meeting their information needs through correcting the anomalies of unavailability of media-formats, contents of

International Association of School Librarianship

https://www.iasl-online.org/ 
media-formats, out-dated media-formats, and unavailability of equipment for media-format use and lack of recording studio for producing and use of voice related media-formats. It is justifiable to believe that such an improvement will be of tremendous help to the students in achieving success in education, health, career/ vocation choices, managing their handicapping condition, and an overall integration into society through erasing the feelings of exclusion. Also, increasing access to the students' libraries media-formats and locations and plugging the holes identified in library services will contribute to increased library use by visually impaired students. It is evident that despite the inadequacies of their school libraries as indicated in the findings of the study, the students still make regular use of the library, an indication that improvements to the libraries in their services, media-formats availability and accessibility, will yield immediate results in improving user-satisfaction.

Moreover, addressing all the identified inadequacies in the joint variables of information needs, library service, media-format availability and accessibility will positively influence library use among the students with visual impairment. An achievement of this goal at any point, will possibly contribute in improving the total quality of education provided for the students with visual impairment, qualifying it on that note, as truly inclusive.

\section{Recommendations}

The following recommendations are given in line with the findings of this study:

1. Schools providing inclusive education in Oyo State and by extension Nigeria should show interest in catering for the interest of students with visual impairment by providing special fund for the provision of media-formats suitable for this category of students which will enable them correct the porosity presently witnessed and that periodic self and/or external checks should be established to monitor progress.

2. Owner governments of inclusive education in schools should as a matter of urgency employ or fund the training of librarians versed with the knowledge of providing service for students with visual impairment as a move towards improving the services in their school libraries for these students. 
3. Inclusive education secondary schools should seek ways to partner with interested local and international NGOs and other donor agencies to improve their mediaformats and facilitate improvements to service delivery.

4. School libraries involved in inclusive education schools should form a consortium for resource sharing, exchange of ideas on improvements to library service for the students with visual impairment and for periodic peer checks.

5. Agencies of government concerned with policy formulation and monitoring such as the Federal Ministry of Education and the National Education Research and Development Council (NERDC) at federal level as well as Secondary Education Management Boards in the states should seek collaboration with authors, publishers and printers of regularly recommended books in schools, with a view to producing alternative versions in braille and speech-media. This will improve local availability of those materials and possibly enable inclusive education school libraries to acquire them and bridge the availability gap in media-formats.

\section{References}

Abdull, M. M., Sivasubramaniam, S., Murthy, G. V. S., Gilbert, C., Abubakar, T., Ezelum, C., \& Rabiu, M. M. (2009). Causes of blindness and visual i m p a i $r$ m e $n$ t i n Nigeria: The Nigeria National blindness and visual impairment survey. Investigative Ophthalmology \& Visual Science. September. 50.9:4114-4120.

Agbaje, S. A. \& Olabode, S. O. (2000) Resources availability to the visually impaired library users in Nigeria: the way out. Journal of Association of Libraries for the visually impaired 1.1:67-73. Ajogwu, M.N. (2006). The role of non-governmental organizations (NGO's) in providing library and information services to two disadvantaged groups in Nigeria. Global review of library and information science. 2: 78-89.

Akakandelwa, A. \& Munsanje, J. (2012). Provision of learning and teaching materias for pupils with visual impairment: results from a National a survey of Zambia. British Journal of Visual Impairment. 30 (42): 49

Albitz, R.S. (2002). Electronic resource librarians in academic libraries: a position announcement analysis, 1996-2001. Libraries and the academy.2 (4):589-600.

International Association of School Librarianship

https://www.iasl-online.org/ 
Alemna A. A. \& Dodoo, V. (2003). An assessment of library services for the visually handicapped in Ghana. Journal of Association of Libraries for the visually impaired 2(1): 32-35.

Atinmo, M. I. (2000). Availability and accessibility of library resources for the visually handicapped in Nigeria: the way forward. Journal of Association of Libraries for the Visually Impaired 1 (1): 1523.

Atkinson, M. T. \& Dhiensa, J. (2007). Improving library services to people with disabilities: the role of technology in public libraries. In Deines-Jones Ed. Improving library services to people with disabilities. Oxford: Chandos Publishing

Babalola, Y. T. \& Haliso, Y. (2011). Library and Information Services to the Visually Impaired-The Role of Academic Libraries. Canadian Social Science. 7(1), 140-147. Retrieved from http://www.cscanada.net on March 24, 2018

Bassey, B.A. (2006). User-satisfaction with services in three academic libraries in Cross River State: a comparative study. Global Review of Library and Information Science. 9 (2): 21-29.

Bello, A. \& Musa, I.F. (2005). Information needs and Information seeking behavior of postgraduate students: A case study of the University of Abuja, Nigeria. Gateway Library Journal. 8 (1/2): 9-18

Bello, L. \& Adeleke, M. (2009). A clarion call: societal responsibilities to persons with special needs. Ibadan: Radiance Educational Publishers. Gordon, C.A. (2009b). An emerging theory for evidence based information literacy instruction in school libraries, Part 2: Building a culture of inquiry. Evidence based library and information practice, 4(3), 19-45.

Beverly, A. C., Bath, A. P. \& Barber, R. (2011). Health and social care information for visually-impaired people. Aslib Proceedings: New Information Perspectives. 63. (2/3): 256-274.

Brazier, H. (2007). The role and activities of IFLA libraries for the blind section. Library Trends. 55.4:864-878.

Brophy, P. (2007). The Library in the twenty-first century. London: Facet Publishers

Ekwelem, V. O. (2013). Library services to disabled students in the digital era: challenges for outcome assessment. Library Philosophy and Practice (e-journal) paper 970. Accessed 26th November 2013 from http://www.digitalcommons.unl.edu/ libphilprac/970

Ekwelem, V. O. (2013). Library services too disabled students in the digital era: Chalenges for outcome assessment. Library Philosophy and Practice (e-journal). 970. Retrieved from http://digitalcommons.unl.edu/libphilprac/970, on March 24, 2018

Eneh, A.C. (2005). A study of user satisfaction in the libraries of John Harris (University of Benin) and Ambrose Ali (Edo State) University. Dissertation. Library and Information Science. Social Sciences. Abia State University, Uturu. Fawole, I., Egbokhare, F.O., Itiola, O.A., Odejide, A.I. \& Olayinka, A.I. ( 2006 ) . Definition, spectrum and types of research. Methodology of basic and applied research 2nd ed. In: Olayinka, A.I., Taiwo, V.O., Raji-Oyelade, A. \& Farai, I.P. (Eds). Ibadan: The Postgraduate School University of Ibadan.1-17.

Haladu, S. (2007). Attitudes and beliefs about disability in Nigeria. In: Abang, T.B., Ozoji , E.D. \& Okuoyibo, J.M. (Eds). The practice and future of special needs education in Nigeria: a book of readings. Jos: Department of Special Education and Rehabilitation Sciences, University of Jos. 
Hall, T., Healey, M. \& Harrison, M. (2002). Fieldwork and disabled students: discourses of exclusion and inclusion. Retrieved Jan.5 2009, from http://www.jstor.org/ stable/3804543.

Handa, K., Dairoku, H., \& Toriyama, Y. (2010). Investigation of priority needs in t e r m s of museum service accessibility for visually impaired visitors. The British Journal of Visual impairment. 28.3:221-234

Hernon, P. \& Calvert, P. (2006). Improving the quality of library services for students with disabilities. Westport, Connecticut: Libraries Unlimited.

Herriot, T.K. 2006. An increasingly diverse student population: a rationale for consideration of universal access at postsecondary institutions. In: Hernon, P. \& Calvert, P. (Eds). Improving the quality of library services for students with disabilities. Westport, CT: Libraries Unlimited.

Ibenne, S. (2016). Library services, media formats availability and accessibility as predictors of usersatisfaction among secondary school students with visual impairment in South-Eastern Nigeria. An Unpublished PhD Thesis submitted to the Department of Library, Archival and Information Studies, University of Ibadan, Nigeria.

Idiodi, E.A. \& Igbinosa, I.O. (2003). Coping with users' frustration in academic libraries in Nigeria: University of Benin experience. Communicate: Journal of Library and Information Science. 5 (1): 8-13.

Idowu, A.O. (2005). Overcoming anxiety in library use in Nigeria: an overview. Owena Journal of Library and Information science. 2 (1): 35-42.

Ifidon, S.E. \& Ifidon, E.I. (2007). New directions in African library management. Ibadan: Spectum Books. International Federation of Library Associations and Institutions (IFLA). (2005). Libraries for the Blind in the Information Age: Guidelines for development. IFLA Professional Reports. 86

Iroegbu, V. U. (2006). Inclusive education for visually impaired children. In: Adelowo, T., Osasuyi, N. \& Ajobiewe, T. (Eds). Special Education in Nigeria: a search for new direction (A book of reading in honour of Dr. T. C. Obani. Oyo: School of Special Education, Federal College of Education (Special), Oyo, Oyo State, Nigeria.

Iweha, C. C. (2003). Networking library Services for the visually impaired in South Western Nigeria. Journal of Association of Libraries for the Visually Impaired. 2(1): 8-17. John-Okeke, R. (2006). Interface model for information utilization in research institutions. Lagos Journal of Library and Information Science. 3 (2): 147-152

Kakai, M., Ikoja-Odongo, R. \& Kigongo-Bukenya, I.M.N. (2004). A study of the Information seeking behavior of undergraduate students of Makerere University, Uganda. World libraries. 14 (1). Retrieved on February 202018 from http:// www.worlib.org/vol14no1/index

Kalia, A., Legge, E. G., Roy, R. 7 Ogale, A. (2001). Assessment of indoor route-finding technology for people who are visually impaired. Journal of visual impairment and blindness.135-147

International Association of School Librarianship https://www.iasl-online.org/ 
Karen, H. (2003). Developing accessible library services. Library + Information Update. 2 (11): 50-52.

Kassim, O. O. \& Maduagwu, D. K. (2006). The impact of Library on the reading n e e d s of the visually impaired. In: Adelowo, T., Osatuyi, N. \& Ajobiewe, T. (Eds) .Special Education in Nigeria: A search for New Direction ( A book of reading in honour of Dr. T. C. Obani). Oyo: School of Special Education, Federal College of Education (Special), Oyo, Oyo State, Nigeria.

Keefer, R., Kakumanu, P. \& Bourbakis, N. (2009). A wearable document reader for the visually impaired: Dewarping and segmentation. International Journal on Artificial Intelligence tools. 18 (3): 467486

Kerkmann, F. \& Lewandowski, D. (2012). Accessibility of web search engines: towards a deeper understanding of barriers for people with disabilities. Library Review. 6 (8/9): 608-621

Lee, S., Nam, T., \& Nam, Y. (2013). Revising cataloguing rules and standards to $m$ e e t the needs of people with disabilities: a proposal for South Korea. Library Resources and Technical Services. 57 (1): $18-21$

Lee, Y.S. (2007). Integrating people with disabilities into mainstream library services. Paper presented at World Library and Information Congress: 73rd IFLA General Conference and Council, 19-23 August. Retrieved February, 222018 from http:// www.ifla.org/IV/ifla73/index.htm

Levitt, T. (2000). Everybody's right to access. Public Library Journal. 15 (4):115-116.

Maduagwu, D. K. \& Ojewande, K. A. (2006). Library and information services for people with special needs. The Special Educator 5 (1): 81-85.

Mahmood, K. (2003). A comparison between weeded competencies of A c a d e m i c Librarians and LIS circular in Pakistan. The Electronic Library. 21 (2): 101-105.

Mason, K. (2000). Are there simply too many user groups in academic library setting? Journal of Academic Librarianship. 26 (1): 30-33.

McIntyre, A.M. (2004). Public library services for children with special needs. Rural Libraries. 24 (2): 21-31

Miller, L. (2004). User satisfaction surveys. APLIS, 17 (3): 125-133.

Morris, B. J. (2004). Administering the School Library Media Centre 4th ed. Westport, Connecticut: Libraries Unlimited.

Nielsen, G.S. \& Irvall, B. 2005. Access to libraries checklist: A practical tool. Retrieved January 20, 2009 from http://www.ifla.org/IV/ifla?programme.htm Nitecki, D. (2000). Measuring service quality at Yale University's library. Journal of Academic Librarianship.26.2:259-273

Nkiko, C. \& Ilo, P.I. (2006). User's satisfaction in academic libraries: issues and strategies for intervention. Global Review of Library and Information Science. 9 (2): 10-20

Nnadozie, C. O. (2006). Information needs and information seeking behaviour of visually handicapped persons in Owerri, Nigeria. The Research Librarian: Journal of the Nigerian Library Association Abia State. 1 (1): 116-131. 
Ochoggia, R.E. (2003). Persons with Disabilities Bill 2002: Implications concerning visual disabilities for academic library and information services in Kenya. New library world. 104.7/8:307-312.

Ocloo, M. A. (2004). The attitude of children with low vision towards Braille as a system of written communication in the schools for the blind in Ghana. African blindness services: Proceedings of the third Africa forum 23-27 May. Midrand, South Africa, .44-52

Ogba, U. (2000). Library and Information services to the visually and physically handicapped in Library for the handicapped, Imo State Library Board, Owerri, Journal of Association of Libraries for the Visually Impaired, 1 (1): 10-14.

Ogunrombi, S.A. (2000). Library Instruction and the use of document collections in an academic library: a case study of the University of Ilorin Library. Journal of Curriculum and Instruction. 2 (1\&2): 144-158.

Olaojo, P.O. \& Akewukere, M.A. (2004). Effects of study habits, information accessibility and use of learning outcomes of postgraduate students in university of Ibadan, Nigeria. Nigerian Library and Information Science Review. 22 (1): 38-45.

Omotayo, B.O (2010) Access, use, and Attitudes of Academics toward Electronic journals: A case study of Obafemi Awolowo University, Ile-Ife. Library Philosophy and Practice.

Omusi, C. (2004). Nigerian Human Rights. Disabilities: Physically disabled People, Youths/Adolescents. Retrieved February, 182018 from http://www.ashoka.org/ fellos/viewprofiles3icfm?reid=96459

Ononogbo, R. U. (2003). User satisfaction in a depressed economy. In: Amaeshi, B. (Eds). Classical readings in African library development. Lanham: The Scarecrow Press. 261-274.

Osinuga, M. A. (2003). The Need for inter library co-operation in providing services for the visually impaired in Nigeria. Journal of Association of Libraries for the Visually Impaired, 2 (1): 25-31.

Oyedun, G.U. (2006). Assessment of physical facilities and readers' satisfaction: a case study of Federal University of Technology Minna Library. Borno Library, Archival and Information Science Journal. 5 (1).

Oyegade, E. A. (2003). Inter library Cooperation in providing services for the visually impaired. Journal of Association of Libraries for the Visually Impaired, 2 (1): 18-24.

Ratna, B. (2007). Development oriented library services for the visually challenged in West Bengal, India. Paper presented at the World Library and Information Congress: 73rd IFLA. General Conference and council 19-23 August.

Rayini, J. (2017). Library and information services to the visually impaired persons (2017). Library Philosophy and Practice (e-journal). Retrieved from http:// digitalcommons.unl.edu/libphilprac/1510, on March 24, 2018

Saha, B., Bhowmick, B, \& Sinha, A. (2009). An embedded solution for visually impaired. Proceedings of the 13th IEEE International Symposium on Consumer Electronics (ISCE 2009): 467-471

International Association of School Librarianship https://www.iasl-online.org/ 
Salaam, M.O. (2006). Access to serials and their utilisation in meeting the research needs of Postgraduate students in university of Agriculture libraries in Nigeria. Seminar presented at the Department of Library, Archival and Information Studies, University of Ibadan.

Schmetzke, A. (2001). Digitization of library information and its accessibility for people with disabilities. Encyclopaedia of Information Science and Technology, Vol. 2. Hershey: Idea Group Reference.

Sokale A. A. (2005) Meeting the United Nation's standard Rule 5 on the equalization of opportunities for persons with disabilities: how far have we gone in Nigeria? The Special Educator, 4(1): 86-91.

Suamure, K. \& Given, L. M. (2004). Digitally enhanced? An examination of the information behaviors of visually impaired post-secondary students. The Canadian Journal of Information and Library Science. 28 (2): 25-42.

Tinerella, P. \& Dick, M.A. (2005). Academic reference service for the visually impaired: a guide for the non-specialist. College and research libraries news. 66 (1): 29-32

Totterdell, A. (2005). An introduction to library and information work. London: Facet publishing.

Ugwu, F. C. (2009). Users's satisfaction with the resources and services of Federal College of Freshwater fisheries Technology and Federal College of Wildlife Management Libraries, New Bussa, Nigeria. Unpublished MLIS Dissertation, University of Ibadan.

Uhegbu, A.N. (2001). The Information user: Issues and themes. Enugu: John Jacobs

UNESCO. (2003). Overcoming exclusion through inclusive approaches in education: a challenge. A vision-conceptual paper. Paris: UNESCO.

University of Washington. (2002). Universal access: electronic resources in libraries, sample presentation script. DO-IT contact information. Disabilities, Opportunities, Internetworking \& Technology. Retrieved on March, 22, 2018 from http:// www.washington.edu/doit/brochures/mailto.html

White, B. (2012). Guaranteeing access to knowledge: The role of libraries. WIPO Magazine. 4. Retrieved on March 22, 2018 from http://www.wipo.int/wipo_magazine/en/2012/04/article_0004.html

Whitmire, E. (2006). The relationship between undergraduates' background characteristics and college experiences and their academics library uses. College and Research Libraries 62 (2): 528-540.

World Health Organization. 2012. Global Data on visual impairments 2010. WHO/NMH/ PBD/12.01. Retrieved on March 22, 2018 from http://www.who.int 


\section{Appendix 1}

Table 1 Respondents' Opinion on Time of Visual Impairment

\begin{tabular}{|l|l|l|}
\hline Response & Frequency & Percentage \\
\hline From birth & 9 & 16.7 \\
\hline At Primary school & 33 & 61.1 \\
\hline At Secondary school & 8 & 14.8 \\
\hline No response & 4 & 7.4 \\
\hline Total & 54 & 100.0 \\
\hline
\end{tabular}

Table 2Respondents' Opinion on Cause of Visual Impairment

\begin{tabular}{|l|l|l|}
\hline Cause of Visual Impairment & Frequency & Percentage \\
\hline Disease & 20 & 37.0 \\
\hline Accident & 20 & 37.0 \\
\hline Birth defect & 12 & 22.2 \\
\hline Use of treatment drug & 2 & 3.7 \\
\hline Total & 54 & 100.0 \\
\hline
\end{tabular}

Table 3Respondents' Opinion on Disease that Cause Visual Impairment

\begin{tabular}{|l|l|l|}
\hline Type of Disease & Frequency & Percentage \\
\hline Cataract & 3 & 5.6 \\
\hline Glaucoma & 19 & 35.2 \\
\hline
\end{tabular}

International Association of School Librarianship https://www.iasl-online.org/ 


\begin{tabular}{|l|l|l|}
\hline Measles & 8 & 14.8 \\
\hline Scarlet fever & - & - \\
\hline Small pox & - & - \\
\hline River blindness & 4 & 7.4 \\
\hline Trachoma & - & - \\
\hline Nutritional deficiency & 3 & 5.6 \\
\hline Brain tumour & - & - \\
\hline Epilepsy & - & - \\
\hline Meningitis & - & - \\
\hline Multiple Sclerosis & - & - \\
\hline Syphilis & - & - \\
\hline Gonorrhoea & - & - \\
\hline
\end{tabular}

Table 4Respondents' Opinion on Accident that Cause Visual Impairment

\begin{tabular}{|l|l|l|}
\hline Type of Accident & Frequency & Percentage \\
\hline Explosion & - & - \\
\hline Firearm & 3 & 5.6 \\
\hline Toxic substance & 8 & 14.8 \\
\hline Alcohol poison & - & - \\
\hline Vehicle crash & - & - \\
\hline $\begin{array}{l}\text { Workplace/Occupational } \\
\text { accident }\end{array}$ & - & - \\
\hline Playground accident & 20 & 37.0 \\
\hline Domestic accident & - & - \\
\hline
\end{tabular}

Table 5Respondents' Opinion on the Time they Start Using Braille

\begin{tabular}{|l|l|l|}
\hline Response & Frequency & Percentage \\
\hline
\end{tabular}




\begin{tabular}{|l|l|l|}
\hline Before primary school & 3 & 5.6 \\
\hline At primary school & 43 & 79.6 \\
\hline At secondary school & 8 & 14.8 \\
\hline
\end{tabular}

International Association of School Librarianship https://www.iasl-online.org/ 